\title{
Overeducated Immigrants in the Canadian Labour Market: Evidence from the Workplace and Employee Survey
}

\author{
STEVEN WALD
}

\author{
Economics Unit, Atkinson Faculty of Liberal and Professional Studies \\ York University, Toronto
}

TONY FANG

School of Administrative Studies, Atkinson Faculty of Liberal and Professional Studies York University, Toronto

\begin{abstract}
Dans cet article, nous examinons la question de la surqualification des immigrants sur le marché du travail au Canada. Nous utilisons des données de 1999 tirées de l'Enquête sur le milieu de travail et les employés pour analyser les déterminants de la surqualification et ses effets sur les revenus de travail. On trouve, dans la littérature actuelle, de nombreuses études sur les effets de la surqualification; toutefois, celle-ci présente la première évaluation du rendement de l'éducation au Canada réalisée sur la base du nombre d'années de scolarité nécessaires pour répondre aux exigences reliées à un emploi, telles que celles-ci sont perçues par les travailleurs. On observe que, en comparaison avec les travailleurs nés au Canada, les immigrants récents sont beaucoup plus touchés par la surqualification, et que, pour eux, le rendement que devrait procurer un plus haut degré de scolarité est relativement faible. Ce phénomène semble expliquer une part importante de l'écart qui existe entre les salaires des immigrants récents et ceux des travailleurs nés au Canada.
\end{abstract}

Mots clés : surqualification, immigrants, revenus de travail, rendement de l'éducation, immigration

This paper addresses the overeducation of recent immigrants in the Canadian labour market. Data from the 1999 Workplace and Employee Survey are used to explore the determinants and earnings consequences of overeducation. Although a well-developed body of literature examines the earnings consequences of overeducation, this paper presents the first Canadian estimates of returns to years of schooling that are contingent upon perceived job requirements. Compared with Canadian-born workers, recent immigrants are found to have a relatively high incidence of overeducation and to earn relatively low returns for surplus schooling. These are shown to be major contributors to the earnings gap between recent immigrants and workers born in Canada.

Keywords: overeducation, immigrants, earnings, returns to education, immigration 
Many newcomers have trouble finding work that allows them to fully use their skills and experience. Their unemployment and underemployment represent more than just a drag on Canada's productivity. It is a human tragedy, and basic decency dictates that it not be allowed to continue.

-Monte Solberg, Minister of Citizenship and Immigration, 20 March 2006

\section{INTRODUCTION}

$\mathrm{T}$ he underutilization of immigrants' skills has emerged as a major public policy issue in Canada. As the above quote attests, the issue was clearly recognized by the federal minister in charge of the immigration portfolio in 2006. As another example of its place high on the radar screen of Canadian politicians, the leader of the opposition party in Ontario released an examination of the issue with the unambiguous title, "Ontario's Skilled Immigrants: Unmet Expectations, Unfulfilled Responsibilities, A Time For Action." In his description of meeting Ontario residents in his capacity as a public figure, Tory (2006) recounts that "the most frequent story I have experienced, certainly in Ontario's urbanized communities and most definitely in the Greater Toronto Area, is the story of the immigrant who came to Canada with skills or credentials, often years earlier . . . struggling to support their family due to chronic underemployment."

Recent data confirm these impressions. For example, according to the 2001 Census, among immigrants with a university education 25 percent of males and 38 percent of females were working in jobs that, at most, required high school education (Galarneau and Morissette 2004), compared with 12 percent of Canadian-born males and 13 percent of Canadian-born females. Data from the Survey of Labour and Income Dynamics (SLID) reveal that 52 percent of recent immigrants with a university degree worked in a job requiring only high school education at some point during the 1993-2001 pe- riod, nearly double the proportion of Canadian-born (Li, Gervais, and Duval 2006). Data from the Longitudinal Survey of Immigrants to Canada (LSIC) also indicate substantial job mismatch; for example, only 42 percent of working-age immigrants who arrived in Canada between April 2001 and May 2002 found work in their intended occupations within two years (Statistics Canada 2003).

An issue that logically flows from the above figures is the magnitude of the economic returns that immigrants receive for their educational attainment, particularly surplus education, in the Canadian labour market. This is an important issue for a variety of reasons. First, Canada selects economic immigrants on the basis of a system that heavily rewards educational attainment. In the most recent version of the "Point System," which came into effect in 2002, applicants in the "Skilled Worker" category can earn 25 of the 67 points necessary for admission into Canada for their educational attainment. ${ }^{1}$ Second, immigrants have faced declining earnings in Canada over the past three decades despite being increasingly educated (Aydemir and Skuterud 2004). Hence, it seems plausible that deteriorating immigrant economic performance and low returns to education may be linked. ${ }^{2}$ And third, demographic projections show that Canadian population growth will rely increasingly on immigration; according to one forecast, immigration is expected to account for all net labour-force growth by 2011 (Human Resources Development Canada 2002). Therefore, the relatively low earnings of educated immigrants will have a growing drag on aggregate incomes in Canada.

While there have been a number of studies examining the returns to immigrants' education in the Canadian context (Ferrer and Riddell 2008; Reitz 2001; Sweetman 2004), to our knowledge, only one study has directly considered the impact of overeducation (Galarneau and Morissette 2004). This lack of attention is somewhat surprising given the prevalence of immigrant overeducation as described above, as well as the well-developed body of literature that examines the earnings consequences of 
overeducation. ${ }^{3}$ On the other hand, there were no published studies examining the relationship between educational mismatch and wages in Canada until quite recently (Vahey 2000). Most Canadian studies on overeducation neglect the immigrant population because of the particular research focus (e.g., literacy, the Canadian post-secondary education system) or because of the absence, or unacceptably small numbers, of immigrant observations within the data sets employed (Boothby 1999; Frenette 2004).

In the one paper exploring the linkage between immigrant overeducation and earnings, Galarneau and Morissette (2004) use data from the 2001 Census and find that recent immigrants employed in full-time jobs requiring no more than high school education face about a 40 percent earnings deficit relative to their (immigrant) counterparts in jobs requiring a university degree. An interesting and more surprising finding is that the earnings of overeducated immigrants were also substantially below those of the overeducated Canadian-born.

In this paper we examine the impacts of overeducation on immigrants' earnings in the $\mathrm{Ca}$ nadian labour market from a slightly different perspective. Specifically, we utilize the framework most commonly appearing in the overeducation literature that enables one to examine returns to school contingent upon job requirements. In more precise terms, a decomposition of respondents' years of education permits the estimation of returns to schooling according to whether those years of education are required for the job, exceed job requirements, or are in deficit of job requirements. Moreover, whereas Galarneau and Morissette (2004) examine one particular, albeit probably the most important, type of overeducation, the data set that we use captures many different magnitudes of educational mismatch.

This paper is organized into sections as follows: We explore some reasons why immigrants may face heightened amounts of mismatch, examine recent studies on immigrant earnings, outline the data and methodological approach, and present our findings in the context of other empirical examinations of earnings consequences of overeducation in Canada. Finally, we offer some policy recommendations.

\section{Explaining Overeducation}

Why might immigrants face a heightened incidence of overeducation? A number of hypotheses have been advanced. The first explanation-which renders the existence of overeducation consistent with the assumptions of human capital theory-is that while immigrants may be categorized as overeducated, their surplus education compensates for education of inferior quality or other human capital deficiencies. For example, a Statistics Canada (2007) study examining the employment of immigrants four years after arrival concludes that there is a significant positive relationship between the ability to speak English and the likelihood of having an appropriate job. Second, if immigrants are discriminated against by Canadian employers during the hiring process, the relative lack of decent job offers will induce them to make greater compromises in terms of job match (Battu and Sloane 2002). Indeed, a recent case heard before the Canadian Human Rights Tribunal involving an immigrant from India with a $\mathrm{PhD}$ focused squarely on this issue (Canadian Human Rights Tribunal 2006). ${ }^{4}$ Third, given their status as labour market entrants, mismatches might be more prevalent as newcomers learn about the labour market. Fourth, it might simply be that job match quality is secondary to more pressing concerns. While it is not surprising that immigrants escaping political persecution would put a lower priority on the quality of job match, survey responses reveal that even principal applicants in the "Economic Class" of immigrants cited reasons other than job prospects as the most important determinant of their settlement location decision (Statistics Canada 2003,15 ). Finally, immigrant skills may not be fully utilized when Canadian licensing bodies or employers fail to recognize foreign credentials or work experience (Reitz 2001). 


\section{Returns to Immigrant Education}

As previously mentioned, a number of studies have examined the returns to immigrants' education in the Canadian labour market. A finding common to most research is that immigrants receive a smaller earnings premium for formal education compared with the Canadian-born (Ferrer, Green, and Riddell 2005). According to Reitz (2001), a generalization that can be drawn from this research is that the estimated return to a year of schooling for immigrants is about half that accruing to the native-born. Why should immigrants' education be rewarded less than that of Canadians? In addition to the reasons articulated earlier (e.g., discrimination, failure to recognize foreign credentials), one strand in the literature hypothesizes that the skills embodied in the education of immigrants are, in some respects, inferior to those of the Canadian-born population and that the observed returns reflect this. Research testing this hypothesis has examined heterogeneity in school quality and literacy skills (Alboim, Finnie, and Meng 2005; Statistics Canada 2007; Sweetman 2004).

Sweetman (2004), using data from multiple censuses, explores the role of source country educational quality in returns to schooling. Supplementing census data with school quality measures for 87 countries, he concludes that there is substantial correlation between average source country school quality and Canadian labour market earnings. For instance, parameter estimates imply that moving up from the 25th to the 75th percentile of the school quality index is associated with a 10 percent increase in annual earnings.

Ferrer, Green, and Riddell (2005) use the Ontario Immigrant Literacy Survey to examine the impact of literacy skills on immigrant earnings and find that differences in literacy account for a large amount of the higher earnings of Canadian-born workers. For example, among the university educated, literacy differences account for about two-thirds of the earnings gap between immigrants and the Canadianborn. Alboim, Finnie, and Meng (2005), using the
1989 Survey of Literacy Skills Used in Daily Activities, similarly find that an important reason for the discounting of immigrants' foreign education is language ability.

\section{Data ANd Methodological Approach}

Data are drawn from the Canadian Workplace and Employee Survey (WES; Statistics Canada 1999). The WES is a linked file consisting of both employer and employee components and covers a broad range of topics from both the demand and the supply side of the labour market. Employers are sampled by physical location, and employees are then sampled within each location from employer-provided lists. The survey excludes locations in the Yukon, Nunavut, and Northwest Territories. Also excluded are positions in agriculture; fishing; road, bridge, and highway maintenance; government services; and religious organizations. ${ }^{5}$ The initial wave of the WES was conducted during the summer and fall of 1999. Responses were received from 6,322 business locations and 23,540 employees.

For the present study, the key WES data include information on earnings, worker educational attainment, perceptions of job requirements, and date of immigration. While data on country of origin and language proficiency are absent from the WES, responses to questions on ethnicity and foreign language usage at home will serve as proxy measures.

The WES contains certain data rendering it particularly well suited for studying the impact of overeducation on earnings. For instance, it contains a direct measure of an individual's total work experience in addition to a measure of job tenure with the current firm. The survey also contains detailed information on the extent of workplace training. These high-quality measures of work experience and training are particularly important in light of the hypothesis that overeducated workers possess lower levels of other forms of human capital, namely, work experience and training. 
The sample of interest consists of paid workers who were between the ages of 18 and 64 in 1999. These criteria result in a sample of 23,296 workers from 5,714 workplaces. Of these workers, 19,690 are Canadian-born and 3,606 are immigrants. For this analysis, we focus on the economic performance of those who immigrated in the decade prior to the survey date. To facilitate comparison with other studies of immigrant earnings, we exclude individuals who immigrated during the survey year or in the year immediately preceding (i.e., 1998 and 1999). Removing these individuals from our sample results in 23,252 observations of which 3,562 are immigrants, including 778 that we label as "recent" (i.e., those who immigrated between 1989 and 1997).

\section{Key Variables and Measures}

In the overeducation literature, four approaches are typically used to ascertain the match between a job's entry and/or performance requirements and an individual's educational attainment (Wald 2005):

- comparison of a worker's educational attainment with the education level that the worker believes to be necessary for either job entry or performance;

- the respondent's perception of being overeducated or overqualified;

- comparison of a worker's educational attainment with the educational requirements for the position (as specified by job analysts); and

- deviation from the average level of educational attainment within a narrowly defined occupation.

With data from the WES, the first of these four approaches can be utilized. ${ }^{6}$ Specifically, an individual's educational attainment can be compared with his or her responses to the following question: "What is the minimum level of education required for this job?" Note that while this question can be reasonably interpreted as asking about either the requirements to be hired or those necessary for job performance, it has been pointed out that both in- terpretations have elicited similar responses (McGuinness 2006).

Based on the comparison between the survey respondent's educational attainment and perceived minimum education required for the job, we derive a set of three dichotomous variables characterizing the fit as overeducated, matched, or undereducated. ${ }^{7}$ We also derive a continuous version whereby years of schooling $\left(S^{a}\right)$ are separated into three components: years of schooling required for the job $\left(S^{r}\right)$, years of surplus education or overschooling $\left(S^{0}\right)$, and years of deficit or underschooling $\left(S^{u}\right){ }^{8}$

While the self-assessed overeducation measure that we adopt may be criticized for its subjectivity, we feel it confers two major advantages over external measures. First, it is a job-specific rather than an occupational-specific measure. Thus, it avoids the risk of misclassification solely due to heterogeneity within an occupation. And second, external assessments often rely on occupational taxonomies that are infrequently updated by government analysts. An OECD (Organisation for Economic Co-operation and Development) analysis of Canadian policies aimed at developing skilled workers concluded that "occupational classifications are slow to incorporate newly emerging fields, particularly in science and technology, or changing skill requirements within occupations" (Baygan 2004, 11). Given the high number of recent immigrants in Canada employed in computer-related occupations, and the rapidly changing nature of these occupations, relying on respondents' own assessments of the skills required to perform their jobs seems to be the preferred measurement approach.

\section{Sample Characteristics}

Table I indicates weighted sample means according to immigration status. Consistent with other data sets, the wages of recent immigrants are well below that of Canadian-born workers ( $\$ 16.08$ versus $\$ 18.48)$. These inferior wages cannot be attributed to lower educational attainment as recent immigrants are a very well educated group. For example, 34.5 percent of recent immigrants are university 
TABLE 1

Weighted Means by Immigration Status

\begin{tabular}{|c|c|c|c|c|}
\hline Variables & $\begin{array}{l}\text { Canadian- } \\
\text { Born }\end{array}$ & $\begin{array}{l}\text { Non-Recent } \\
\text { Immigrants }\end{array}$ & $\begin{array}{c}\text { Recent } \\
\text { Immigrants }\end{array}$ & Total \\
\hline Hourly wage (\$) & 18.48 & 20.06 & 16.08 & 18.60 \\
\hline $\begin{array}{l}\text { Education - job match (continuous variables) } \\
\text { Years of education } \\
\text { Years of required education } \\
\text { Years of overeducation } \\
\text { Years of undereducation }\end{array}$ & $\begin{array}{r}13.2 \\
12.3 \\
1.3 \\
0.4\end{array}$ & $\begin{array}{r}13.6 \\
12.4 \\
1.6 \\
0.5\end{array}$ & $\begin{array}{r}14.0 \\
12.2 \\
2.2 \\
0.3\end{array}$ & $\begin{array}{r}13.1 \\
12.3 \\
1.4 \\
0.4\end{array}$ \\
\hline $\begin{array}{l}\text { Education - job match (dichotomous variables) } \\
\text { Education matched } \\
\text { Overeducated } \\
\text { Undereducated }\end{array}$ & $\begin{array}{l}0.516 \\
0.313 \\
0.172\end{array}$ & $\begin{array}{l}0.488 \\
0.346 \\
0.166\end{array}$ & $\begin{array}{l}0.412 \\
0.478 \\
0.110\end{array}$ & $\begin{array}{l}0.508 \\
0.324 \\
0.169\end{array}$ \\
\hline $\begin{array}{l}\text { Highest level of educational attainment } \\
\text { Less than high school education } \\
\text { High school graduation } \\
\text { Some college } \\
\text { Some university } \\
\text { College diploma } \\
\text { Undergraduate degree } \\
\text { Professional degree } \\
\text { Graduate degree }\end{array}$ & $\begin{array}{l}0.119 \\
0.221 \\
0.102 \\
0.051 \\
0.330 \\
0.141 \\
0.007 \\
0.031\end{array}$ & $\begin{array}{l}0.101 \\
0.191 \\
0.089 \\
0.053 \\
0.295 \\
0.187 \\
0.014 \\
0.070\end{array}$ & $\begin{array}{l}0.086 \\
0.173 \\
0.056 \\
0.065 \\
0.275 \\
0.226 \\
0.010 \\
0.109\end{array}$ & $\begin{array}{l}0.115 \\
0.215 \\
0.099 \\
0.052 \\
0.323 \\
0.151 \\
0.008 \\
0.039\end{array}$ \\
\hline Age (years) & 39.0 & 44.1 & 37.5 & 39.6 \\
\hline Female ( 1 if yes, 0 if no) & 0.522 & 0.530 & 0.485 & 0.522 \\
\hline Married ( 1 if yes, 0 if no) & 0.543 & 0.711 & 0.710 & 0.572 \\
\hline Children aged 2 and under ( 1 if yes, 0 if no) & 0.083 & 0.080 & 0.117 & 0.084 \\
\hline Children aged 3 to 5 ( 1 if yes, 0 if no) & 0.102 & 0.102 & 0.183 & 0.106 \\
\hline Non-European ethnic background ( 1 if yes, 0 if no) & 0.080 & 0.517 & 0.762 & 0.166 \\
\hline $\begin{array}{l}\text { Foreign language mostly spoken at home } \\
(1 \text { if yes, } 0 \text { if no) }\end{array}$ & 0.011 & 0.284 & 0.650 & 0.073 \\
\hline Full-time work experience prior to present job (years) & 8.2 & 9.5 & 7.5 & 8.3 \\
\hline $\begin{array}{l}\text { Reason for leaving last job } \\
\text { Laid off from last job or contract ended } \\
(1 \text { if yes, } 0 \text { if no) } \\
\text { Left last job for current better job ( } 1 \text { if yes, } 0 \text { if no) } \\
\text { Other reasons or not applicable ( } 1 \text { if yes, } 0 \text { if no) }\end{array}$ & $\begin{array}{l}0.085 \\
0.134 \\
0.781\end{array}$ & $\begin{array}{l}0.060 \\
0.089 \\
0.851\end{array}$ & $\begin{array}{l}0.120 \\
0.173 \\
0.707\end{array}$ & $\begin{array}{l}0.083 \\
0.129 \\
0.788\end{array}$ \\
\hline Unemployment in previous 5 years (months) & 1.2 & 0.8 & 1.4 & 1.2 \\
\hline
\end{tabular}


TABLE 1

(Continued)

\begin{tabular}{lrrrr}
\hline Variables & $\begin{array}{c}\text { Canadian- } \\
\text { Born }\end{array}$ & $\begin{array}{c}\text { Non-Recent } \\
\text { Immigrants }\end{array}$ & $\begin{array}{c}\text { Recent } \\
\text { Immigrants }\end{array}$ & Total \\
\hline Job tenure (years) & 8.4 & 9.9 & 3.8 & 8.4 \\
Part-time job (1 if yes, 0 if no) & 0.147 & 0.140 & 0.115 & 0.144 \\
$\begin{array}{l}\text { Union/collective bargaining agreement } \\
\quad(1 \text { if yes, } 0 \text { if no) }\end{array}$ & 0.295 & 0.252 & 0.145 & 0.283 \\
Workplace size (natural log of total employment) & 4.3 & 4.4 & 4.0 & 4.3 \\
Non-profit firm (1 if yes, 0 if no) & 0.221 & 0.201 & 0.095 & 0.213 \\
Foreign firm (1 if yes, 0 if no) & 0.163 & 0.189 & 0.204 & 0.168 \\
Member of a workplace team or self-directed & & & & \\
$\quad$ workgroup (1 if yes, 0 if no) & 0.482 & 0.526 & 0.472 & 0.488 \\
Incentive pay received ( 1 if yes, 0 if no) & 0.074 & 0.055 & 0.070 & 0.071 \\
Job rotation (1 if yes, 0 if no) & 0.163 & 0.192 & 0.210 & 0.169 \\
Per capita training expenditures (\$ 00s) & 3.15 & 2.65 & 2.26 & 3.05 \\
Workplace part-time rate & 0.273 & 0.242 & 0.238 & 0.268 \\
Observations & 19,690 & 2,784 & 778 & 23,252 \\
\hline
\end{tabular}

Note: Mean values for region, industry, and occupation available upon request.

Source: Authors' compilation.

graduates compared with 17.9 percent of Canadianborn workers. In terms of years of education, recent immigrants bring nearly one year more of education to the labour market than the Canadian-born ( 14.0 versus 13.2 years). Strikingly, nearly half $(47.8$ percent) of the recent immigrants are labelled as overeducated according to our dichotomous measure of overeducation, compared with about one-third of the Canadian-born. In terms of years of surplus education, recent immigrants have nearly one additional year of overeducation compared with Canadian-born workers ( 2.2 versus 1.3 years). In fact, despite their significantly higher levels of educational attainment, the jobs of recent immigrants are perceived to require slightly less education than those of the
Canadian-born (12.2 years compared with 12.3 years).

Table 2 describes the sample of individuals according to the match between educational attainment and perceived job requirements. The data indicate that recent immigrants are more likely to be overeducated than non-recent immigrants or the Canadian-born. Recent immigrants comprise 6.0 percent of overeducated workers and 3.0 percent of educationally matched workers, whereas the Canadianborn are underrepresented within the overeducated category (79.8 percent of overeducated compared with 83.9 percent of matched workers). These figures are consistent with other variables related to immigrant 
TABLE 2

Weighted Means by Educational Match

\begin{tabular}{|c|c|c|c|}
\hline Variable & Undereducated & Matched & Overeducated \\
\hline Hourly wage (\$) & 21.08 & 18.51 & 17.42 \\
\hline \multicolumn{4}{|l|}{ Education - job match (continuous variables) } \\
\hline $\begin{array}{l}\text { Years of education } \\
\text { Years of required education } \\
\text { Years of overeducation } \\
\text { Years of undereducation }\end{array}$ & $\begin{array}{r}12.2 \\
14.6 \\
0.0 \\
2.4\end{array}$ & $\begin{array}{r}13.0 \\
13.0 \\
0.0 \\
0.0\end{array}$ & $\begin{array}{r}14.3 \\
10.1 \\
4.2 \\
0.0\end{array}$ \\
\hline $\begin{array}{l}\text { Highest level of educational attainment } \\
\text { Less than high school education } \\
\text { High school graduation } \\
\text { Some college } \\
\text { Some university } \\
\text { College diploma } \\
\text { Undergraduate degree } \\
\text { Professional degree } \\
\text { Graduate degree }\end{array}$ & $\begin{array}{l}0.286 \\
0.170 \\
0.138 \\
0.042 \\
0.242 \\
0.122 \\
0.000 \\
0.000\end{array}$ & $\begin{array}{l}0.132 \\
0.248 \\
0.105 \\
0.059 \\
0.309 \\
0.114 \\
0.012 \\
0.023\end{array}$ & $\begin{array}{l}0.000 \\
0.186 \\
0.068 \\
0.046 \\
0.388 \\
0.222 \\
0.006 \\
0.085\end{array}$ \\
\hline $\begin{array}{l}\text { Immigration period } \\
\text { Born in Canada } \\
\text { Immigrated before } 1970 \\
\text { Immigrated between } 1970 \text { and } 1979 \\
\text { Immigrated between } 1980 \text { and } 1988 \\
\text { Immigrated between } 1989 \text { and } 1999\end{array}$ & $\begin{array}{l}0.843 \\
0.074 \\
0.040 \\
0.017 \\
0.026\end{array}$ & $\begin{array}{l}0.839 \\
0.051 \\
0.045 \\
0.032 \\
0.033\end{array}$ & $\begin{array}{l}0.798 \\
0.048 \\
0.050 \\
0.044 \\
0.060\end{array}$ \\
\hline Age (years) & 42.3 & 39.7 & 38.0 \\
\hline Female ( 1 if yes, 0 if no) & 0.480 & 0.534 & 0.524 \\
\hline Married ( 1 if yes, 0 if no) & 0.634 & 0.582 & 0.524 \\
\hline Children aged 2 and under ( 1 if yes, 0 if no) & 0.078 & 0.088 & 0.081 \\
\hline Children aged 3 to 5 ( 1 if yes, 0 if no) & 0.092 & 0.112 & 0.103 \\
\hline Non-European ethnic background ( 1 if yes, 0 if no) & 0.136 & 0.158 & 0.195 \\
\hline Foreign language mostly spoken at home ( 1 if yes, 0 if no) & 0.055 & 0.061 & 0.103 \\
\hline $\begin{array}{l}\text { Reason for leaving last job } \\
\text { Laid off from last job or contract ended ( } 1 \text { if yes, } 0 \text { if no) } \\
\text { Left last job for current better job ( } 1 \text { if yes, } 0 \text { if no) } \\
\text { Other reasons or not applicable ( } 1 \text { if yes, } 0 \text { if no) }\end{array}$ & $\begin{array}{l}0.074 \\
0.091 \\
0.835\end{array}$ & $\begin{array}{l}0.076 \\
0.125 \\
0.799\end{array}$ & $\begin{array}{l}0.098 \\
0.155 \\
0.747\end{array}$ \\
\hline Unemployment in previous 5 years (months) & 0.9 & 1.0 & 1.5 \\
\hline Job tenure (years) & 10.9 & 8.6 & $\begin{array}{c}7.0 \\
\text {... continued }\end{array}$ \\
\hline
\end{tabular}


TABLE 2

(Continued)

\begin{tabular}{lccc}
\hline Variable & Undereducated & Matched & Overeducated \\
\hline $\begin{array}{l}\text { Part-time job (1 if yes, } 0 \text { if no) } \\
\text { Union/collective bargaining agreement coverage }\end{array}$ & 0.109 & 0.141 & 0.169 \\
$\quad(1$ if yes, 0 if no) & 0.320 & 0.298 & 0.241 \\
Workplace size (natural log of total employment) & 4.5 & 4.3 & 4.1 \\
$\begin{array}{l}\text { Member of a workplace team/self-directed workgroup } \\
\quad(1 \text { if yes, } 0 \text { if no) }\end{array}$ & 0.552 & 0.507 & 0.424 \\
Job rotation (1 if yes, 0 if no) & 0.175 & 0.172 & 0.159 \\
Per capita training expenditures (\$ 00s) & 3.71 & 3.12 & 2.60 \\
Workplace part-time rate & 0.236 & 0.260 & 0.296 \\
Observations & 4,133 & 11,899 & 7,220 \\
\hline
\end{tabular}

Source: Authors' compilation.

characteristics. For example, individuals of nonEuropean ethnic background comprise a greater share of the overeducated category (19.5 percent) than the matched workers (15.8 percent), and those in households where a foreign language is most often spoken comprise 10.3 percent of the overeducated sample compared with 6.1 percent of matched workers.

Overeducated workers earn somewhat less than matched workers or undereducated workers. Compared with workers who are educationally matched, overeducated workers earn $\$ 1.09$ less per hour on average. These inferior earnings exist in spite of their higher levels of educational attainment than matched workers ( 14.3 years compared with 13.0 years). The positive relationship between the hourly wage rate and years of required education hints at the efficacy of decomposing years of education in this manner.

The argument that higher levels of education compensate for lower levels of experience and training seems plausible given the mean differences presented in Table 2. For example, overeducated workers are younger than matched workers (38.0 years compared with 39.7 years), have fewer years of firm-specific job tenure ( 7.0 years compared with 8.6 years), and work in firms with lower per capita training expenditures ( $\$ 260$ compared with $\$ 312$ ).

Overeducated workers do not appear to differ in a substantial manner from matched workers along gender lines, marital status, or according to the presence of children. Personal employment history does seem to affect the likelihood of overeducation as those with higher levels of unemployment and those who involuntarily left previous positions have a heightened incidence of overeducation. A number of workplace variables appear to determine the probability of overeducation. Specifically, union membership, workplace size, and membership in a workplace team or self-directed work group are all negatively associated with overeducation, whereas job rotation and working part-time appear to increase the likelihood of overeducation. 


\section{FINDINGS}

Multinomial logit estimations are utilized to investigate the probability of educational mismatch. This estimation technique is appropriate where the discrete dependent variable covers two or more outcomes that do not have a natural ordering. We are particularly interested in whether the negative relationship between overeducation and time spent in Canada is statistically significant when the other potential determinants discussed above are considered.

We use survey estimation commands with the employee survey weights provided in the WES in all our estimations to account for the fact that once an establishment has been selected in the survey, the assumption that a given worker is randomly sampled from the overall population of workers is no longer appropriate. ${ }^{9}$ That is, the errors generated are corrected for the common components associated with a cluster of workers from a given workplace. These estimation commands also return representative results and provide heteroskedasticity-robust standard errors.

Table 3 presents marginal effects of the probability of overeducation estimated from two multinomial logit specifications. The first model examines mismatch conditional on individual attributes, while the second specification also includes job characteristics. In both specifications, while recent immigrants are found to have a heightened incidence of overeducation, the increased probabilities are not statistically significant. This finding is primarily due to the very close association between immigration period and the language used most often within the household. For instance, when foreign language is excluded from Model 1, recent immigrants are 13.2 percentage points more likely to be overeducated, which is significant at the 1 percent threshold. ${ }^{10}$ In the specifications presented in Table 3, individuals living in homes where a foreign language was the language most often spoken have a heightened probability of overeducation of 13.9 percentage points and 9.8 percentage points. This finding suggests that
English or French language proficiency and country of origin are important determinants of overeducation.

Relative to those with high school education or less, individuals with post-secondary education credentials are more likely to be overeducated. This finding is somewhat to be expected since the measurement of overeducation involves a comparison between attained credentials and job requirements. The probability of overeducation rises quite dramatically with successive credentials. For example, in Model 2, those with undergraduate degrees are 45.0 percentage points more likely to be overeducated while those with graduate degrees face an increased probability of 63.4 percentage points.

Consistent with the job shopping exhibited among younger workers, the probability of overeducation decreases with age. Specifically, a one-year increase in the worker's age decreases the probability of overeducation by roughly 2 to 3 percentage points. None of the variables included in the specification designed to capture potential household constraints were found to be statistically significant in the anticipated direction. Instead, being married or having children two years of age or younger reduces the probability of overeducation in a statistically significant manner. Despite the bivariate relationships between overeducation and a worker's previous job separation, the estimates from the multinomial logit were not significant. On the other hand, workers with greater periods of unemployment were found to be at an increased risk of overeducation.

Model 2 also includes a number of job variables in the multinomial logit. Workers in firms with higher per capita training expenditures face a lower likelihood of overeducation as do members of workplace teams or self-directed workgroups. Conversely, workers in firms that employ more part-time workers and those who participate in job rotations were significantly more likely to be overeducated (marginal effects of 0.135 and 0.013 , respectively). These results are consistent with the notion that 
TABLE 3

The Determinants of Overeducation (Mean Probability $=0.324$ )

\begin{tabular}{|c|c|c|c|}
\hline \multirow[t]{3}{*}{ Variables } & \multicolumn{3}{|c|}{ Probability of Overeducation } \\
\hline & \multirow[t]{2}{*}{ Mean } & \multicolumn{2}{|c|}{ Prob } \\
\hline & & Model 1 & Model 2 \\
\hline \multicolumn{4}{|l|}{ Immigration period } \\
\hline Born in Canada & 0.905 & - & - \\
\hline Immigrated before 1970 & 0.054 & -0.006 & 0.000 \\
\hline Immigrated between 1970 and 1979 & 0.046 & 0.008 & 0.011 \\
\hline Immigrated between 1980 and 1988 & 0.033 & 0.043 & 0.035 \\
\hline Immigrated between 1989 and 1997 & 0.040 & 0.051 & 0.056 \\
\hline \multicolumn{4}{|l|}{ Educational attainment } \\
\hline High school graduation or less & 0.480 & - & - \\
\hline College & 0.323 & $0.221^{* \star *}$ & $0.297^{\star \star \star}$ \\
\hline Undergraduate degree & 0.150 & $0.330^{* * *}$ & $0.450 * \star \star$ \\
\hline Professional degree & 0.008 & 0.032 & $0.228^{\star \star *}$ \\
\hline Graduate degree & 0.039 & $0.518^{* * *}$ & $0.634^{* \star \star}$ \\
\hline Age & 39.577 & $-0.029 * \star \star *$ & $-0.018^{* * *}$ \\
\hline $\mathrm{Age}^{2}(/ 100)$ & 16.782 & $0.031^{\star * *}$ & $0.019 * * *$ \\
\hline \multicolumn{4}{|l|}{ Gender } \\
\hline Male & 0.478 & - & - \\
\hline Female & 0.522 & -0.009 & 0.002 \\
\hline \multicolumn{4}{|l|}{ Marital status } \\
\hline Not married & 0.428 & - & - \\
\hline Married & 0.572 & $-0.042^{\star \star}$ & $-0.035^{*}$ \\
\hline \multicolumn{4}{|l|}{ Children } \\
\hline No children aged 2 and under & 0.916 & - & - \\
\hline Children aged 2 and under & 0.084 & $-0.049^{*}$ & -0.042 \\
\hline No children aged 3 to 5 & 0.894 & - & - \\
\hline Children aged 3 to 5 & 0.106 & -0.024 & -0.019 \\
\hline \multicolumn{4}{|l|}{ Ethnic origin } \\
\hline European & 0.834 & - & - \\
\hline Non-European & 0.166 & -0.011 & -0.013 \\
\hline \multicolumn{4}{|l|}{ Language used most often at home } \\
\hline English or French & 0.927 & - & - \\
\hline Foreign language mostly spoken at home & 0.073 & $0.139 * \star \star$ & $0.098^{\star \star}$ \\
\hline \multicolumn{4}{|l|}{ Reason left last job } \\
\hline Other reason for leaving or not applicable & 0.788 & - & - \\
\hline Laid off from last job or contract ended & 0.083 & 0.033 & 0.032 \\
\hline \multirow[t]{2}{*}{ Left last job for current better job } & 0.129 & 0.017 & 0.013 \\
\hline & & & ... continued \\
\hline
\end{tabular}


TABLE 3

The Determinants of Overeducation (Mean Probability $=0.324$ )

\begin{tabular}{|c|c|c|c|}
\hline \multirow[t]{3}{*}{ Variables } & \multicolumn{3}{|c|}{ Probability of Overeducation } \\
\hline & \multirow[t]{2}{*}{ Mean } & \multicolumn{2}{|c|}{ Prob } \\
\hline & & Model 1 & Model 2 \\
\hline Unemployment in previous 5 years (months) & 1.151 & $0.004^{\star \star}$ & $0.003^{\star}$ \\
\hline $\begin{array}{l}\text { Employment } \\
\text { Full-time job } \\
\text { Part-time job }\end{array}$ & $\begin{array}{l}0.856 \\
0.144\end{array}$ & & $0 . \overline{047}$ \\
\hline $\begin{array}{l}\text { Union status or collective bargaining agreement } \\
\text { Not union member or covered } \\
\text { Union member or covered }\end{array}$ & $\begin{array}{l}0.717 \\
0.283\end{array}$ & & -0.003 \\
\hline Workplace size (natural log of total employment) & 4.261 & & -0.006 \\
\hline Per capita training expenditure $(\$ 00)$ & 3.050 & & $-0.003^{\star \star \star}$ \\
\hline Workplace part-time rate & 0.268 & & $0.135^{\star \star \star}$ \\
\hline $\begin{array}{l}\text { Employee participation } \\
\text { Not a member of a workplace team or self-directed workgroup } \\
\text { Member of a workplace team or self-directed workgroup }\end{array}$ & $\begin{array}{l}0.512 \\
0.488\end{array}$ & & $-0.090^{\star \star *}$ \\
\hline $\begin{array}{l}\text { Job rotation } \\
\text { Never participate in job rotation } \\
\text { Occasionally or frequently participate in job rotation }\end{array}$ & $\begin{array}{l}0.831 \\
0.169\end{array}$ & & $0 . \overline{013^{\star * *}}$ \\
\hline Observations & & 23,252 & 23,252 \\
\hline Fstatistic & & $2134.78^{* * *}$ & $1097.55^{\star \star \star}$ \\
\hline
\end{tabular}

Note: Numbers in the mean column refer to cell proportions for categorical variables and mean values for continuous variables for the total observations in the sample. Numbers in the $\mathrm{Pr}$ ob column represent percentage-point changes based on multinomial logit estimates (available upon request). Model 1 also contains regional categories, while Model 2 also contains industry categories.

*Denotes significance at the 10 percent level. ${ }^{*}$ Significance at the 5 percent level. ${ }^{* *}$ Significance at the 1 percent level. Source: Authors' compilation.

firms can adopt high-performance workplace practices that may result in higher-skilled jobs and more empowered employees.

To analyze the effect of educational mismatch on earnings, we rely on a standard Mincerian semilogarithmic wage equation with the modification that years of educational attainment are decomposed:

$$
\begin{aligned}
\ln W_{i j}=\alpha+\beta_{1} S_{i j}^{r} & \beta_{2} S_{i j}^{o}+\beta_{3} S^{u}{ }_{i j}, \\
& +X_{i j} \gamma+Y_{i j} \delta+\varepsilon_{i j}
\end{aligned}
$$


where $\ln \mathrm{W}_{\mathrm{ij}}$ is the natural logarithm of the observed hourly wage of the $i^{\text {th }}$ worker in the $j^{\text {th }}$ workplace, $S^{r}$ ij is years of required schooling of the $i^{\text {th }}$ worker in the $j^{\text {th }}$ workplace, $S^{0}$ ij is years of surplus schooling of the $i^{\text {th }}$ worker in the $j^{\text {th }}$ workplace (overeducation), $S^{u}{ }_{i j}$ is years of deficit schooling of the $i^{\text {th }}$ worker in the $j^{\text {th }}$ workplace (undereducation), $X_{\mathrm{ij}}$ is a vector of (other) personal characteristics for the $i^{\text {th }}$ worker in the $j^{\text {th }}$ workplace, $\gamma$ is a vector of estimated slope coefficients for worker characteristics, $Y_{\mathrm{j}}$ is a set of characteristics of the $j^{\text {th }}$ workplace for worker $i, \delta$ is a vector of estimated slope coefficients for workplace characteristics, and $\varepsilon_{i j}$ is an error term. " This variant on the human capital earnings function has been termed the ORU (Overeducation/Required education/Undereducation) specification. We commence the analysis by regressing wages solely as a function of worker characteristics since an inferior job match is reflected in most job characteristics (e.g., part-time, industry, occupation). This parsimonious approach also eases comparison with studies adopting this framework (see, for example, Chiswick and Miller 2005; Daly, Buchel, and Duncan 2000; and Green, Kler, and Leeves 2007).

Table 4 shows the results from the earnings regressions with separate estimations for the Canadian-born and recent immigrants. Columns 1 and 3 provide results based on the standard methodology for estimating returns to schooling for comparative purposes, while columns 2 and 4 give the results generated by the ORU model. In addition to the ORU specifications presented in Table 4, we estimated equations where educational categories were interacted with experience and job tenure, and where educational categories were interacted with our proxy for language proficiency. Since virtually all of these interactions were statistically insignificant and the impacts on estimated returns to education were trivial, we present findings based only on our parsed equations. ${ }^{12}$ For the Canadianborn, the return to an additional year of schooling is 8.3 percent whereas for recent immigrants the return is 6.7 percent. Despite the differences in data sets employed and in the specifications, these estimated returns are fairly similar to those presented by Schaafsma and Sweetman (2001) using 1996 Census data.

When years of education are decomposed, returns to years of overeducation are found to be positive but smaller than returns to years of required education. In both of these ORU estimates (i.e., columns 2 and 4) the implicit assumption within human capital theory that returns to education are not contingent on job requirements (i.e., $b_{1}=b_{2}=b_{3}$ ) is rejected. ${ }^{13}$ The estimates for the Canadian-born exceed typical results whereas the estimates for recent immigrants are at the mid-point of the range of similar studies; an analysis of 45 studies from numerous countries covering various time periods by Hartog (2000) determined that returns to overeducation average about one-half to two-thirds of the returns to required education. For recent immigrants, the returns to overeducation are 60.9 percent of those to required education (0.053/0.087), while for the Canadianborn they are 74.5 percent $(0.076 / 0.102)$. Perhaps this disparity reflects differential access to the most coveted jobs in the labour market; that is, jobs that apparently offer unnecessary pay are largely unavailable to new Canadians. Alternatively stated, while the returns to both types of education are substantially lower for recent immigrants than for the Canadian-born, a wider disparity exists in the returns to surplus schooling. This finding is consistent with comparable studies contrasting immigrant and native-born overeducation in Great Britain, the United States, and Australia (Battu and Sloane 2002; Chiswick and Miller 2005; Green, Kler, and Leeves 2007).

Comparing columns 3 and 4 reveals that controlling for educational match substantially reduces the negative impact of foreign language on earnings. In other words, the negative earnings impact of being in a household where a foreign language is most often spoken is largely due to its effect on the likelihood of overeducation. As previously stated, 


\begin{tabular}{|c|c|c|c|c|}
\hline \multirow[t]{2}{*}{ Variables } & \multicolumn{2}{|c|}{ Canadian-Born } & \multicolumn{2}{|c|}{ Recent Immigrants } \\
\hline & (1) & (2) & (3) & (4) \\
\hline Years of education & $\begin{array}{c}0.083^{\star \star \star} \\
(23.76)\end{array}$ & - & $\begin{array}{c}0.067^{\star \star \star} \\
(7.31)\end{array}$ & - \\
\hline Years of required education & - & $\begin{array}{c}0.102^{\star \star \star} \\
(27.12)\end{array}$ & - & $\begin{array}{c}0.087^{\star \star *} \\
(9.65)\end{array}$ \\
\hline Years of overeducation & - & $\begin{array}{c}0.076^{\star \star \star} \\
(19.31)\end{array}$ & - & $\begin{array}{c}0.053^{\star \star \star} \\
(4.80)\end{array}$ \\
\hline Years of undereducation & - & $\begin{array}{c}-0.028^{\star \star \star} \\
(4.29)\end{array}$ & - & $\begin{array}{l}-0.002 \\
(0.09)\end{array}$ \\
\hline Female & $\begin{array}{c}-0.203^{* * *} \\
(13.62)\end{array}$ & $\begin{array}{c}-0.198^{\star \star \star} \\
(13.66)\end{array}$ & $\begin{array}{c}-0.261^{\star \star \star} \\
(4.87)\end{array}$ & $\begin{array}{c}-0.276^{\star \star \star} \\
(5.71)\end{array}$ \\
\hline Married & $\begin{array}{c}0.155^{\star \star \star} \\
(11.00)\end{array}$ & $\begin{array}{c}0.140^{\star * \star} \\
(9.82)\end{array}$ & $\begin{array}{c}-0.015 \\
(0.32)\end{array}$ & $\begin{array}{c}-0.006 \\
(0.14)\end{array}$ \\
\hline Non-European & $\begin{array}{l}0.001 \\
(0.05)\end{array}$ & $\begin{array}{c}-0.002 \\
(0.08)\end{array}$ & $\begin{array}{c}-0.184^{\star \star \star *} \\
(2.64)\end{array}$ & $\begin{array}{c}-0.189 * * \star \\
(2.91)\end{array}$ \\
\hline Foreign language spoken at home & $\begin{array}{l}0.036 \\
(0.77)\end{array}$ & $\begin{array}{l}0.052 \\
(1.18)\end{array}$ & $\begin{array}{c}-0.097^{\star} \\
(1.91)\end{array}$ & $\begin{array}{c}-0.044 \\
(0.93)\end{array}$ \\
\hline Experience & $\begin{array}{c}0.016^{\star \star \star} \\
(6.35)\end{array}$ & $\begin{array}{c}0.014^{* * *} \\
(5.97)\end{array}$ & $\begin{array}{c}0.029^{\star \star \star} \\
(3.57)\end{array}$ & $\begin{array}{c}0.021^{* * *} \\
(2.84)\end{array}$ \\
\hline Experience $^{2}(/ 100)$ & $\begin{array}{c}-0.029 * \star \star \\
(3.19)\end{array}$ & $\begin{array}{c}-0.025^{\star * \star *} \\
(2.74)\end{array}$ & $\begin{array}{c}-0.084^{\star \star *} \\
(3.06)\end{array}$ & $\begin{array}{c}-0.064^{* *} \\
(2.54)\end{array}$ \\
\hline Job tenure & $\begin{array}{c}0.036^{\star \star \star \star} \\
(14.78)\end{array}$ & $\begin{array}{c}0.033^{\star \star * *} \\
(14.27)\end{array}$ & $\begin{array}{c}0.045^{\star \star \star} \\
(3.05)\end{array}$ & $\begin{array}{c}0.048^{* \star \star} \\
(3.43)\end{array}$ \\
\hline Job tenure ${ }^{2}(/ 100)$ & $\begin{array}{c}-0.058^{\star \star \star *} \\
(7.73)\end{array}$ & $\begin{array}{c}-0.054^{\star \star \star} \\
(7.45)\end{array}$ & $\begin{array}{c}-0.137^{\star} \\
(1.71)\end{array}$ & $\begin{array}{c}-0.177^{\star *} \\
(2.27)\end{array}$ \\
\hline Constant & $\begin{array}{c}1.196^{* \star \star} \\
(22.87)\end{array}$ & $\begin{array}{c}0.984^{\star \star \star *} \\
(18.70)\end{array}$ & $\begin{array}{c}1.590^{* * \star} \\
(7.48)\end{array}$ & $\begin{array}{c}1.345^{\star \star \star} \\
(6.98)\end{array}$ \\
\hline Observations & 19,690 & 19,690 & 778 & 778 \\
\hline$R$-squared & 0.340 & 0.380 & 0.434 & 0.489 \\
\hline
\end{tabular}

Notes: Models also include regions (6 categories). Absolute values of $t$-statistics based on robust standard errors are in parentheses.

"Denotes significance at the 10 percent level. ${ }^{* *}$ Significance at the 5 percent level. ${ }^{* *}$ Significance at the 1 percent level. Source: Authors' compilation. 
this variable is not an ideal measure of language proficiency but instead imperfectly measures both a respondent's language proficiency and country of origin. Controlling for educational mismatch does not alter the estimated earnings impact of ethnicity for recent immigrants; relative to those of European descent, non-Europeans earned about 20.8 percent less. $^{14}$

A somewhat unusual finding is that returns to years of work experience (prior to current job) are comparable in dollar terms between the Canadianborn and recent immigrants. Specifically, the partial effect of a year of labour market experience on wages is roughly $\$ 0.18$ for both groups. ${ }^{15}$ While this finding suggests that immigrants' foreign work experience is not discounted by employers, this work experience could, unfortunately, not be partitioned exactly into the component attained in Canada and that attained abroad due to the nature of the data. ${ }^{16}$ We defined prior work experience to exclude the experience attained in the current (Canadian) job to circumvent this issue, but the results obtained suggest that this problem was only partially rectified. The partial effect of job tenure was observed to have greater returns for immigrants compared with the Canadianborn ( $\$ 0.56$ or 3.5 percent compared with $\$ 0.45$ or 2.4 percent, respectively), ${ }^{17}$ which is consistent with the finding that Canadian work experience has much greater value to immigrants than experience obtained abroad (Schaafsma and Sweetman 2001).

In addition to the results appearing in Table 4, we estimated a number of variations of equation (1). Specifically, we estimated models with the inclusion of workplace variables, as shown in Table 5. A similar pattern regarding economic returns to schooling emerges in Table 5 as in the models restricted to individual characteristics. Specifically, while the Canadian-born are found to have higher returns to years of schooling (0.062 compared with 0.041 ), the relative disparity between returns to required and surplus schooling is larger for recent immigrants. As seen in column 4 , recent immigrants earn about 3.8 percent for each year of surplus schooling compared with 5.8 percent per year of required schooling (i.e., a relative return of 65.5 percent), whereas the respective figures for Canadian-born workers are 6.3 percent and 7.8 percent (i.e., a relative return of 80.8 percent). Two other noteworthy findings from these specifications are the differences in the returns to incentive pay and training expenditures. While Canadian-born workers receive substantial returns for incentive pay such as commission and tips ( 8.4 percent), the increase in the wages of recent immigrants is not significant. This disparity could reflect both customer discrimination as well as productivity differences between recent immigrants and the Canadian-born. Recent immigrants receive a relatively large return from training expenditures; a $\$ 100$ increase in per capita training expenditures results in nearly a 1 percent increase in hourly wages. This reinforces the earlier finding that Canadian work experience is a particularly valuable avenue for improving the human capital of recent immigrants.

While it is common to include occupational variables in earnings regressions, it does not seem entirely appropriate in this context given that overeducation is our main variable of interest. With the inclusion of occupational controls, the coefficient on overeducation reveals the returns to surplus schooling after accounting for the fact that an individual with a given level of education works in a given occupation. This is akin to posing the following question: "What are the returns to a PhD's years of surplus schooling after controlling for the fact that a PhD graduate is driving a taxi?" As seen in the comparison in Table 6, with the inclusion of five fairly broad occupational categories, the estimated returns to required and surplus schooling fall.

Table 7 compares our estimated earnings consequences of overeducation with those of comparable Canadian studies. ${ }^{18}$ All of these other studies utilize a dummy variable approach whereby the estimated coefficient shows the earnings penalty 
TABLE 5

Wage Impacts of Educational Mismatch, Worker Characteristics, and Job Characteristics

\begin{tabular}{|c|c|c|c|c|}
\hline \multirow[t]{2}{*}{ Variables } & \multicolumn{2}{|c|}{ Canadian-Born } & \multicolumn{2}{|c|}{ Recent Immigrants } \\
\hline & (1) & (2) & (3) & (4) \\
\hline Years of education & $\begin{array}{c}0.062^{\star \star \star} \\
(16.98)\end{array}$ & - & $\begin{array}{c}0.041^{\star \star \star} \\
(5.15)\end{array}$ & - \\
\hline Years of required education & - & $\begin{array}{c}0.078^{\star \star \star} \\
(19.21)\end{array}$ & - & $\begin{array}{c}0.058^{\star \star *} \\
(6.29)\end{array}$ \\
\hline Years of overeducation & - & $\begin{array}{c}0.063^{\star \star \star} \\
(16.28)\end{array}$ & - & $\begin{array}{c}0.038^{\star \star \star} \\
(4.15)\end{array}$ \\
\hline Years of undereducation & - & $\begin{array}{c}-0.019^{\star \star \star \star} \\
(3.09)\end{array}$ & - & $\begin{array}{c}-0.013 \\
(0.63)\end{array}$ \\
\hline Female & $\begin{array}{c}-0.156^{\star \star \star} \\
(10.09)\end{array}$ & $\begin{array}{c}-0.148^{* \star \star} \\
(9.72)\end{array}$ & $\begin{array}{c}-0.215^{\star \star \star} \\
(4.43)\end{array}$ & $\begin{array}{c}-0.226^{\star \star \star} \\
(4.84)\end{array}$ \\
\hline Married & $\begin{array}{c}0.123^{\star * *} \\
(9.43)\end{array}$ & $\begin{array}{c}0.116^{\star \star \star} \\
(8.60)\end{array}$ & $\begin{array}{c}-0.019 \\
(0.45)\end{array}$ & $\begin{array}{c}-0.013 \\
(0.32)\end{array}$ \\
\hline Non-European & $\begin{array}{c}-0.022 \\
(1.08)\end{array}$ & $\begin{array}{c}-0.023 \\
(1.16)\end{array}$ & $\begin{array}{c}-0.198^{\star * *} \\
(3.57)\end{array}$ & $\begin{array}{c}-0.201^{\star \star \star} \\
(3.71)\end{array}$ \\
\hline Foreign language spoken at home & $\begin{array}{l}0.035 \\
(0.83)\end{array}$ & $\begin{array}{l}0.042 \\
(1.01)\end{array}$ & $\begin{array}{r}-0.025 \\
(0.60)\end{array}$ & $\begin{array}{c}-0.010 \\
(0.24)\end{array}$ \\
\hline Experience & $\begin{array}{c}0.011^{\star \star \star} \\
(4.93)\end{array}$ & $\begin{array}{c}0.011^{\star \star \star} \\
(4.81)\end{array}$ & $\begin{array}{c}0.022^{\star \star \star} \\
(3.08)\end{array}$ & $\begin{array}{c}0.019^{\star \star \star} \\
(2.67)\end{array}$ \\
\hline Experience $^{2}(/ 100)$ & $\begin{array}{c}-0.017^{\star \star} \\
(2.00)\end{array}$ & $\begin{array}{c}-0.016^{\star} \\
(1.80)\end{array}$ & $\begin{array}{c}-0.062^{\star *} \\
(2.55)\end{array}$ & $\begin{array}{c}-0.054^{\star} \\
(2.25)\end{array}$ \\
\hline Job tenure & $\begin{array}{c}0.027^{\star \star \star} \\
(13.70)\end{array}$ & $\begin{array}{c}0.026^{* \star \star} \\
(13.32)\end{array}$ & $\begin{array}{c}0.054^{\star \star \star} \\
(4.17)\end{array}$ & $\begin{array}{c}0.054^{\star \star \star} \\
(4.13)\end{array}$ \\
\hline Job tenure ${ }^{2}(/ 100)$ & $\begin{array}{c}-0.045^{\star \star \star} \\
(7.50)\end{array}$ & $\begin{array}{c}-0.044^{\star \star \star} \\
(7.37)\end{array}$ & $\begin{array}{c}-0.194^{\star \star \star} \\
(2.69)\end{array}$ & $\begin{array}{c}-0.207^{\star \star \star *} \\
(2.76)\end{array}$ \\
\hline Part-time job & $\begin{array}{l}0.0003 \\
(0.01)\end{array}$ & $\begin{array}{l}0.010 \\
(0.44)\end{array}$ & $\begin{array}{c}-0.029 \\
(0.38)\end{array}$ & $\begin{array}{r}-0.027 \\
(0.36)\end{array}$ \\
\hline Workplace size & $\begin{array}{c}0.047^{\star \star *} \\
(0.047)\end{array}$ & $\begin{array}{c}0.043^{\star * \star} \\
(10.88)\end{array}$ & $\begin{array}{c}0.047^{\star \star} \\
(2.89)\end{array}$ & $\begin{array}{c}0.042^{* *} \\
(2.62)\end{array}$ \\
\hline Union member & $\begin{array}{c}-0.017 \\
(0.93)\end{array}$ & $\begin{array}{c}-0.004 \\
(0.22)\end{array}$ & $\begin{array}{c}-0.033 \\
(0.53)\end{array}$ & $\begin{array}{c}-0.021 \\
(0.35)\end{array}$ \\
\hline Incentive pay & $\begin{array}{c}0.084^{\star \star \star} \\
(2.56)\end{array}$ & $\begin{array}{c}0.084^{\star \star \star} \\
(2.71)\end{array}$ & $\begin{array}{l}0.024 \\
(0.32)\end{array}$ & $\begin{array}{l}0.009 \\
(0.12)\end{array}$ \\
\hline Per capita training expenditures $(/ 100)$ & $\begin{array}{c}0.004^{* \star *} \\
(4.36)\end{array}$ & $\begin{array}{c}0.004^{\star * *} \\
(3.76)\end{array}$ & $\begin{array}{c}0.011^{* * *} \\
(3.64)\end{array}$ & $\begin{array}{c}0.008^{\star \star} \\
(2.56)\end{array}$ \\
\hline Workplace part-time rate & $\begin{array}{c}-0.153^{* \star \star} \\
(-4.06)\end{array}$ & $\begin{array}{c}-0.141^{* * *} \\
(3.79)\end{array}$ & $\begin{array}{c}-0.205 \\
(1.48)\end{array}$ & $\begin{array}{c}-0.169 \\
(1.29)\end{array}$ \\
\hline Constant & $\begin{array}{c}1.613^{\star * *} \\
(28.17)\end{array}$ & $\begin{array}{c}1.433^{* \star \star} \\
(24.56)\end{array}$ & $\begin{array}{c}2.141^{\star \star \star} \\
(8.50)\end{array}$ & $\begin{array}{c}1.952^{\star \star \star} \\
(6.99)\end{array}$ \\
\hline Observations & 19,690 & 19,690 & 778 & 778 \\
\hline$R$-squared & 0.447 & 0.467 & 0.546 & 0.560 \\
\hline
\end{tabular}

Notes: Models also include regions ( 6 categories) and industry sector (14 categories). Absolute values of $t$-statistics based on robust standard errors are in parentheses.

*Denotes significance at the 10 percent level. " * Significance at the 5 percent level. ${ }^{\star \star *}$ Significance at the 1 percent level. Source: Authors' compilation. 
TABLE 6

Wage Impacts of Educational Mismatch, with Occupational Controls

\begin{tabular}{|c|c|c|c|c|}
\hline \multirow[t]{2}{*}{ Variables } & \multicolumn{2}{|c|}{ Canadian-Born } & \multicolumn{2}{|c|}{ Recent Immigrants } \\
\hline & (1) & (2) & (3) & (4) \\
\hline Years of education & $\begin{array}{c}0.041^{* * *} \\
(12.17)\end{array}$ & - & $\begin{array}{c}0.028^{* * *} \\
(3.78)\end{array}$ & - \\
\hline Years of required education & - & $\begin{array}{c}0.054^{\star \star \star} \\
(13.47)\end{array}$ & - & $\begin{array}{c}0.039^{* * *} \\
(4.32)\end{array}$ \\
\hline Years of overeducation & - & $\begin{array}{c}0.044^{* \star *} \\
(12.24)\end{array}$ & - & $\begin{array}{c}0.026^{\star \star *} \\
(2.98)\end{array}$ \\
\hline Years of undereducation & - & $\begin{array}{c}-0.014^{\star \star \star} \\
(2.62)\end{array}$ & - & $\begin{array}{l}-0.021 \\
(0.93)\end{array}$ \\
\hline Observations & 19,690 & 19,690 & 778 & 778 \\
\hline$R$-squared & 0.508 & 0.516 & 0.607 & 0.611 \\
\hline
\end{tabular}

Notes: Models include all variables as specified in Table 4 with the addition of occupational categories. Absolute values of $t$-statistics based on robust standard errors are in parentheses.

***Denotes significance at the 1 percent level.

Source: Authors' compilation.

TABLE 7

Estimated Earnings Impact of Overeducation

\begin{tabular}{|c|c|c|c|c|c|}
\hline \multirow[t]{2}{*}{ Author(s) } & \multirow[t]{2}{*}{ Data (Year) } & \multirow[t]{2}{*}{ Sample Characteristics } & \multirow[t]{2}{*}{ Coefficient } & \multicolumn{2}{|c|}{ Annual Estimate } \\
\hline & & & & Nominal \$ & $2006 \$$ \\
\hline Boothby & IALS (1994) & All post-secondary educated & $-7,197$ & $-7,197$ & $-9,124$ \\
\hline Drolet & WES (1999) & All & -0.107 & $-4,183$ & $-4,885$ \\
\hline \multirow[t]{3}{*}{ Frenette } & NGS (Various) & All college graduates & -0.099 & $-3,030$ & $-3,775$ \\
\hline & & All bachelor degree holders & -0.192 & $-7,382$ & $-9,197$ \\
\hline & & All master degree holders & -0.030 & $-1,484$ & $-1,849$ \\
\hline \multirow[t]{4}{*}{ Wald/Fang } & WES (1999) & Canadian-born ${ }^{\mathrm{a}}$ & -0.026 & $-4,010$ & $-4,683$ \\
\hline & & Recent immigrants ${ }^{a}$ & -0.034 & $-4,921$ & $-5,747$ \\
\hline & & Canadian-born & -0.016 & $-2,375$ & $-2,773$ \\
\hline & & Recent immigrants ${ }^{b}$ & -0.020 & $-2,965$ & $-3,462$ \\
\hline
\end{tabular}

Notes: IALS $=$ International Adult Literacy Survey. WES $=$ Workplace and Employee Survey. NGS $=$ National Graduates Survey. The above calculations convert hourly wages into annual earnings by applying coefficient estimates to mean wages and assuming 2,000 hours worked per year (except for Boothby which is in annual earnings).

aResults from columns 2 and 4 of Table 4 . The coefficient presented is the difference between the estimated returns for surplus schooling less required schooling (0.076-0.102 for Canadian-born and $0.528-0.087$ for recent immigrants). 'Results from columns 2 and 4 of Table 5 . The coefficient presented is the difference between the estimated returns for surplus schooling less required schooling (0.063-0.078 for Canadian-born and $0.038-0.058$ for recent immigrants). Source: Boothby (1999); Drolet (2002); Frenette (2004); Statistics Canada, Workplace and Employee Survey (1999). 
relative to workers with the same level of education who are adequately matched. To derive a similar result based on the ORU specifications, we take the difference in returns to surplus schooling and required schooling multiplied by the mean years of surplus schooling. Thus, the counterfactual we present is the earnings of an immigrant who fully utilizes his or her years of surplus schooling. The estimated annual earnings penalties (expressed in 2006 dollars) attributable to overeducation that we derive are $\$ 4,683$ for the Canadian-born and $\$ 5,747$ for recent immigrants using our specification containing worker attributes. Broadening our model to include workplace attributes results in estimated earnings penalties of $\$ 2,773$ for the Canadian-born. and $\$ 3,462$ for recent immigrants. Table 7 shows that our results are roughly in the middle of the estimates, which range from a low of $\$ 1,849$ to a high of $\$ 9,197$.

While it is somewhat challenging to generalize across studies utilizing different data sets, models, and measurement approaches, it appears that studies restricted to post-secondary graduates generate relatively large estimates of earnings penalties (with the notable exception being the low pay penalty for overeducated master's degree holders). The difference between the overeducation pay penalty for bachelor's and master's degree holders suggests that jobs differing by skill level award surplus skills in a different manner. It seems plausible that in relatively low-skilled positions where turnover is minimal, supervision is close, and an employee has little scope for creativity, there may be little rationale for compensating employees for their surplus schooling. Not surprisingly, the estimated overeducation earnings penalty becomes smaller as more explanatory variables are included in the earnings regression. For example, Boothby (1999) presents a fairly simple model where the only explanatory variables are experience, gender, literacy, education level, and mismatch and consequently derives a large estimated earnings penalty $(\$ 9,124)$. Similarly, when our basic specifications (i.e., those appearing in Table 4) are augmented to include workplace variables, the estimated annual earnings penalty associated with overeducation falls by $\$ 1,910$ for the Canadian-born and $\$ 2,285$ for recent immigrants.

To give a sense of the relative importance of the various wage-determining factors considered in the hourly pay gap between recent immigrants and the Canadian-born, we compute the Blinder-Oaxaca wage decomposition from the results of equation (1). This method decomposes the 0.138 difference in mean log wages (or $\$ 2.40$ as expressed as an hourly wage gap as seen in Table 1) into the portion due to differing endowments between the two groups and that arising from differences in coefficients. From the estimated wage equation, the difference in mean log wages between the Canadian-born and recent immigrants is decomposed as follows:

$$
\begin{aligned}
\ln \bar{W}_{c}-\ln \bar{W}_{i}= & \left(\bar{X}_{c}-\bar{X}_{i}\right) \hat{\beta}_{c}+\left(\bar{Y}_{c}-\bar{Y}_{i}\right) \hat{\delta}_{c} \\
& +\left(\hat{\beta}_{c}-\hat{\beta}_{i}\right) \bar{X}_{i}+\left(\hat{\delta}_{c}-\hat{\delta}_{i}\right) \bar{Y}_{i}
\end{aligned}
$$

where $\beta$ and $\delta$ represent the coefficients for worker (including education) variables and workplace characteristics, respectively. The first two terms on the right-hand side of this equation represent the explained portion due to differences in the mean endowments (i.e., worker and workplace characteristics), while the latter two terms represent the part of the wage gap due to differences in returns for personal and workplace characteristics (evaluated at the mean endowments of recent immigrants). While differences in returns are often equated with discrimination, they also reflect differential circumstances and tastes. For example, workers may rationally accept a wage offer that undervalues their characteristics if the job fits well with other responsibilities (Dougherty 2005).

Table 8 shows the contributions of the explanatory variables to the wage gap between Canadianborn and recent immigrants. More than the entire wage gap is due to differences in returns as recent immigrants actually have an advantage in terms of the endowments of measured productive attributes. The importance of returns to required education and 
TABLE 8

Oaxaca Wage Decomposition

\begin{tabular}{lcc}
\hline Variables & Endowments & Returns \\
\hline Years of required education & 0.008 & 0.240 \\
Years of overeducation & -0.054 & 0.053 \\
Years of undereducation & -0.002 & -0.002 \\
Other characteristics & 0.016 & 0.395 \\
Subtotal & -0.032 & 0.687 \\
Constant & 0.000 & -0.518 \\
Total (\% of total) & $-0.032(-23.4)$ & $0.169(123.4)$ \\
\hline
\end{tabular}

Note: Based on results from Table 4 . Total difference in mean log earnings is 0.138 , which corresponds to an hourly mean wage difference of $\$ 2.40$.

Source: Authors' compilation.

overeducation can be seen from the table; differential returns to years of required education account for about 35 percent of total coefficient differences, while the differential payoff to overeducation accounts for nearly 8 percent of that gap (excluding the constant term). Although recent immigrants bring more years of surplus schooling to the labour market, this endowment advantage is almost entirely offset by the excess returns earned by Canadian-born workers.

Another way to gauge the importance of overeducation on earnings is to ask the following: If all years of immigrants' surplus education are utilized, what is the magnitude of the remaining earnings differential? Assuming 2,000 hours of work per year, we calculate that the mean earnings difference between the Canadian-born and recent immigrants is $\$ 5,605$ in 2006 dollars. ${ }^{19}$ The low estimate of the earnings penalty for recent immigrants of $\$ 3,462$ is 62 percent of this amount, whereas the high estimate of $\$ 5,747$ exceeds it. What if the overeducation pay penalty partly reflects literacy or other unobserved ability differences between the two groups of workers? Frenette (2004) finds that the earnings penalty to overeducation is much smaller in a longitudinal estimation framework that captures unobserved heterogeneity. Specifically, he finds that the earnings penalty for bachelor degree holders ranges from about 22 percent to 56 percent as large as the OLS estimate. Applying these figures to our results yields estimated pay gaps ranging between $\$ 762$ and $\$ 1,939$ (using our lower estimate of $\$ 3,462$ ) and between $\$ 1,264$ and $\$ 3,218$ (using our high estimate of the annual impact of $\$ 5,747$ ). In other words, relative to the earnings difference between recent immigrants and the Canadian-born, the estimated pay impact effect of immigrant overeducation always appears economically meaningful (ranging from 14 to 57 percent of the earnings gap).

\section{Conclusion}

Analysis using the WES data supports the findings from other data sets as well as the substantial anecdotal evidence that recent immigrants face an increased incidence of educational mismatch. Of the immigrants arriving between 1989 and 1997, nearly half were overeducated in 1999 according to data from the WES. Multivariate analysis confirmed that many recent immigrants are especially prone to overeducation. Specifically, those in households 
where a language other than English or French is most often spoken are nearly 10 percentage points more likely to be overeducated controlling for numerous individual and workplace characteristics.

In addition to the heightened incidence of overeducation, this study has shown that immigrants suffer a larger earnings disadvantage from overeducation than the Canadian-born. In fact, relative to Canadian-born workers, the low economic returns accruing to years of surplus schooling basically negate any advantage normally associated with extra years of schooling. Thus, with respect to earnings, a proper job match is relatively more important for recent immigrants than for the Canadian-born. This finding is consistent with research exploring the wage impacts of immigrant overeducation using Canadian census data (Galarneau and Morissette 2004).

Our results offer some guidance regarding finetuning the selection system used for admitting immigrants on the basis of their labour market attributes. A simple modification to the points system based on the results presented here would be to make the number of points awarded to educational attainment contingent on some other selection characteristic that affects the likelihood of overeducation. For example, perhaps applicants with arranged employment, presumably at a level commensurate with their skills, should be given more points for each level of attained education. Similarly, given the link between language proficiency and mismatch, perhaps maximum educational points should be awarded only for those graduate degree holders attaining a certain threshold of literacy. In a sense, this modification would render the current selection system more consistent with the theoretical underpinnings upon which it premised. That is, since skilled-worker immigrants are chosen on the basis of attributes believed to positively influence earnings and long-run adaptability, one could argue that without a certain degree of language proficiency, the human capital embodied in one's education is not truly available to the Canadian labour market.
Before implementing such changes, however, it would be very useful to conduct simulations to assess how these suggestions would alter the distribution of skilled workers by source country.

In a similar vein, given the importance of the job match to the earnings of immigrants, attaching greater weight to the arranged employment criterion seems reasonable. With greater weight attached to arranged employment, one might also consider whether employer characteristics should be considered in the selection process. For example, since we found that employees working in firms with more part-time workers have a higher likelihood of overeducation, a selection system could theoretically favour those planning to work in firms with a greater percentage of full-time employees. We also found that recent immigrants working for firms with high training expenditures have a significant wage advantage. While we suggest that there is scope to give employers more weight within the points system, it is acknowledged that employers are being given an increasing role in immigrant selection as provinces are making increasing use of temporary immigration and Provincial Nominee programs (employer-driven programs that permit nominated individuals to bypass the regular point system).

Numerous commentators have suggested improved credential assessment processes as a means to facilitate the transferability of immigrant skills (Alboim, Finnie, and Meng 2005; Reitz 2001; Tory 2006). Suggestions range from having immigrant credentials assessed as part of the admission process, as is done in Australia (Alboim, Finnie, and Meng 2005), to having provincial governments maintain complete databases of program equivalencies for foreign credentials that could be utilized by employers to assess potential employees (Tory 2006). In the 2005 federal budget, it was also announced that steps would be taken toward the establishment of a Canadian agency for the assessment and recognition of foreign credentials. In light of the prevalence and associated costs of overeducation, measures that can improve the 
signals transmitted by foreign credentials should definitely be explored.

While the above recommendations focus on the matching process that occurs largely before individuals arrive in Canada, there are no doubt numerous worthy initiatives to foster human capital growth in the post-immigration settlement phase. As eloquently put by Foster $(1998,177)$ in his study of Canadian immigration policy, "A broad-based immigration policy that is not grounded in a lifelong learning model-where the strategy is to cultivate skills rather than simply import them-will eventually be an impediment to society as once-needed skills become dated." Policies that promote lifelong and workplace learning-such as the recently introduced Ontario and federal apprenticeship training tax credits-will not only help the integration of new Canadians but also assist the Canadian workforce in general.

Another potential action for government policymakers is the improvement of labour market information. Ideally, a question pertaining to the perceived overqualification or to the minimum educational requirement of a respondent's job could be inserted into Statistics Canada's monthly Labour Force Survey (LFS). Combined with new immigration information in the LFS, this data would give researchers and policy-makers the ability to study this issue of immigrant underemployment in a more timely fashion. It might also give the issues of job quality and underemployment greater media and public policy attention.

\section{Notes}

*The authors thank Seamus McGuinness, Morley Gunderson, colleagues at York, and two anonymous referees for very helpful comments and suggestions. They especially thank Yves Decady of Statistics Canada for his exceptional and unwavering data support. All errors are the responsibility of the authors.

${ }^{1}$ The current passing grade is 67 points out of a possible 100 .
${ }^{2}$ It is noted that Aydemir and Skuterud (2004) do not reach this conclusion.

${ }^{3}$ See McGuinness (2006) for an up-lo-date and thorough review of the literature on overeducation.

${ }^{4}$ The complainant, an immigrant from India with a $\mathrm{PhD}$, put forth the argument that the refusal to hire overqualified immigrants amounted to discrimination since visible minorities face barriers at their appropriate levels of employment that force them to seek lower skilled jobs (Canadian Human Rights Tribunal 2006).

${ }^{5}$ Geographic restrictions are due to cost considerations associated with conducting the survey while some industries are excluded as the workplace survey content is not that relevant (e.g., technology use, collective bargaining, training expenditures).

${ }^{6}$ The third and fourth approach cannot be used since WES data available to researchers via remote access are not coded with sufficiently detailed occupational information (e.g., 4-digit level).

${ }^{7}$ Analysis will focus on the overeducated population due to its policy relevance.

$8^{8}$ i.e., $S^{a}=S^{r}+S^{0}-S^{u}$.

9 "In Stata Version 9, we use the "svyreg" and "svymlogit" commands, the counterparts to "reg" and "mlogit," which are inappropriate in the presence of complex survey data.

${ }^{10}$ Results available upon request.

"In order to decompose actual schooling into required years, surplus years, and deficit years, we assigned the following years to the minimum education required: none (0 if matched, 8 if overeducated), elementary school (8), some secondary school (8), secondary school (12), some post-secondary education (12), trade (14), college (14), undergraduate (16), professional degree (19), graduate (18). We assigned the following years of schooling to actual educational attainment: secondary school graduate (12), trade (14), some college (12), college graduate (14), some university (12), teachers' college (14), university below BSc (14), bachelor's (16), university above bachelor's (18), master's (18), professional degree (19), $\mathrm{PhD}(20)$. We give those with some education, but not the completed credential, 0 years of education in that category in order to avoid a non-graduate being labelled as 
overeducated relative to the lower category. In an examination of earnings effects of job match, Hersch (1991) used three different conversion schemes for "some" schooling and found that results varied little.

${ }^{12}$ These other results are available from the authors upon request.

${ }^{13}$ For the two ORU equations in Table 4, the relevant F statistics corresponding to the Wald tests are $F(2,5486)=112.55$, Prob $>F=0.0000$ and $F(2,611)=8.47$, Prob $>F=0.0002$.

${ }^{14}$ This is calculated as $\mathrm{e}^{-0.189}-1$.

${ }^{15}$ Calculated as $0.014-(0.05 / 100) \times$ experience for Canadian-born where mean experience is 8.178 and mean wage is $\$ 18.48$, and as $0.021-(0.064 / 100) x$ experience for recent immigrants where mean experience is 7.45 and mean wage is $\$ 16.08$.

${ }^{16}$ Specifically, while we have data of immigration and years of total work experience, we do not have a complete work history of one's time spend in Canada (e.g., we do not know how much of the years since immigration was spent not in the labour force or in unemployment).

${ }^{17}$ Calculated as $.033-(.108 / 100) \times$ tenure for Canadian-born where mean tenure is 8.431 , and as 0.048 $(0.354 / 100) \times$ tenure for recent immigrants where mean tenure is 3.834 .

${ }^{18}$ The study by Galarneau and Morissette (2004) did not use an econometric framework to estimate the overeducation pay penalty. The raw weekly earnings gaps presented were $\$ 502$ for university-educated males (equivalent to about $\$ 28,393$ annually) and $\$ 356$ for university-educated females (equivalent to about $\$ 20,135$ annually). Annual estimates could not be derived from the data presented in Vahey (2000).

${ }^{19}$ This is calculated as $2000 \times(\$ 18.48-\$ 16.08) \times$ 1.1677 .

\section{References}

Alboim, N., R. Finnie, and R. Meng. 2005. "The Discounting of Immigrants' Skills in Canada: Evidence and Policy Recommendations." IRPP Choices 11:2.

Aydemir, A. and M. Skuterud. 2004. "Explaining the Deteriorating Entry Earnings of Canada's Immigrant
Cohorts: 1966-2000.” Research Paper No. 225, Statistics Canada, Ottawa.

Battu, H. and P.J. Sloane. 2002. "To What Extent Are Ethnic Minorities in Britain Overeducated?" International Journal of Manpower 23(3):192-208.

Baygan, G. 2004. "Developing Highly Skilled Workers: Review of Canada." Paris: Organisation for Economic Co-operation and Development.

Boothby, D. 1999. "Literacy Skills, the Knowledge Content of Occupations and Occupational Mismatch." Research Report No. W-99-3E, Applied Research Branch, Human Resources Development Canada, Ottawa.

Canadian Human Rights Tribunal. 2006. "Gian Sangha and Canadian Human Rights Commission and Mackenzie Valley Land and Water Board: Reasons for Decision." Available at http://www.chrt-tcdp.gc.ca/ search/files/sangha\%20final\%20decision.pdf

Chiswick, B. and P. Miller. 2005. "Why Is the Payoff to Schooling Smaller for Immigrants?" IZA Discussion Paper No. 1731, Institute for the Study of Labour, Bonn, Germany.

Daly, M., Buchel, F., and G. Duncan. 2000. “Premiums and Penalties for Surplus and Deficit Education: Evidence from the United States and Germany." Economics of Education Review 19(2):169-78.

Dougherty, C. 2005. "Why Are the Returns to Schooling Higher for Women than for Men?" The Journal of Human Resources 40(4):969-89.

Drolet, M. 2002. "Can the Workplace Explain Gender Pay Differentials?" Canadian Public Policy/Analyse de politiques 28:S41-\$63.

Ferrer, A., Green, D., and C. Riddell. 2005. "The Effect of Literacy on Immigrant Earnings." Unpublished manuscript, University of British Columbia, Vancouver.

Ferrer, A. and C. Riddell. 2008. "Education, Credentials, and Immigrant Earnings." Canadian Journal of Economics 41(1):186-216.

Foster, L. 1998. Turnstile Immigration: Multiculturalism, Social Order and Social Justice in Canada. Toronto: Thompson Educational Publishing, Inc.

Frenette, M. 2004. "The Overqualified Canadian Graduate: The Role of the Academic Program in the Incidence, Persistence, and Economic Returns to Overqualification." Economics of Education Review 23:29-45.

Galarneau, D. and R. Morissette. 2004. "Immigrants: Settling for Less?" Perspectives on Labour and Income 5(6):5-16. 
Green, C., Kler, P., and G. Leeves. 2007. "Immigration Overeducation: Evidence from Recent Arrivals to Australia." Economics of Education Review 26(4):420-32.

Hartog, J. 2000. "Over-education and Earnings: Where Are We, Where Should We Go?" Economics of Education Review 19:131-47.

Hersch, J. 1991. "Education Match and Job Match." Review of Economics and Statistics 73:140-44.

Human Resources Development Canada. 2002. Knowledge Matters: Skills and Learning for Canadians. Ottawa: Human Resources Development Canada.

Li, C., Gervais, G., and A. Duval. 2006. "The Dynamics of Overqualification: Canada's Underemployed University Graduates." Cat. No. 11-621-MIE2006039, Analysis in Brief, Statistics Canada.

McGuinness, S. 2006. "Overeducation in the Labour Market." Journal of Economic Surveys 20(3):387-418.

Reitz, J. 2001. "Immigrant Skill Utilization in the Canadian Labour Market: Implications of Human Capital Research." Journal of International Migration and Integration 2(3):347-78.

Schaafsma, J. and A. Sweetman. 2001. "Immigrant Earnings: Age at Immigration Matters." Canadian Journal of Economics 34(4):1066-99.
Statistics Canada. 1999. Workplace and Employee Survey. Electronic Data Dictionary Cat. No. 71-221-XWE. Available at http://www.statcan.ca/english/freepub/71221-XIE/71-221-XIE2007000.htm

- 2003. "Longitudinal Survey of Immigrants to Canada: Process, Progress, and Process." Cat. No. 89-611-XIE, Special Surveys Division, Statistics Canada.

- 2007. "Knowledge of Official Languages among New Immigrants: How Important Is It in the Labour Market? Cat. No. 89-624-XIE, Special Surveys Division, Statistics Canada.

Sweetman, A. 2004. "Immigrant Source Country Educational Quality and Labour Market Outcomes." Research Paper No. 234, Analytical Studies Branch Research Paper Series, Statistics Canada.

Tory, J. 2006. "A Time For Action: Ontario's Skilled Immigrants: Unmet Expectations, Unfulfilled Responsibilities." Available at http://www.ontariopccaucus.com/ documents/TFA_Skilled_Immigrants.pdf

Vahey, S. 2000. "The Great Canadian Training Robbery: Evidence on the Returns to Education Mismatch." Economics of Education Review 19:219-27.

Wald, S. 2005. "The Impact of Overqualification on Job Search." International Journal of Manpower 26(2):140-56. 